OPEN ACCESS

Edited by:

David K. Wright,

University of Oslo, Norway

Reviewed by:

Peter Hopcroft,

University of Birmingham,

United Kingdom

Guillaume Leduc,

UMR7330 Centre Européen de

Recherche et d'enseignement de Géosciences de l'environnement

(CEREGE), France

${ }^{*}$ Correspondence:

Igor M. Venancio

imartins@uni-bremen.de

Specialty section:

This article was submitted to

Quaternary Science, Geomorphology and Paleoenvironment,

a section of the journal

Frontiers in Earth Science

Received: 01 December 2021

Accepted: 14 January 2022

Published: 16 February 2022

Citation:

Venancio IM, Nascimento $R A$,

Santos TP, Belem AL, Lessa DO,

Tiedemann R, Chiessi CM, Mulitza $S$ and Albuquerque ALS (2022) Tropical South American Rainfall Response to

Dansgaard-Oeschger Stadials of

Marine Isotope Stage 5.

Front. Earth Sci. 10:826993.

doi: 10.3389/feart.2022.826993

\section{Tropical South American Rainfall Response to Dansgaard-Oeschger Stadials of Marine Isotope Stage 5}

Igor M. Venancio ${ }^{1,2 *}$, Rodrigo A. Nascimento ${ }^{1}$, Thiago P. Santos ${ }^{1}$, Andre L. Belem ${ }^{3}$, Douglas O. Lessa ${ }^{1}$, Ralf Tiedemann ${ }^{4}$, Cristiano M. Chiessi ${ }^{5}$, Stefan Mulitza ${ }^{2}$ and Ana Luiza S. Albuquerque ${ }^{1}$

${ }^{1}$ Programa de Geociências (Geoquímica), Universidade Federal Fluminense, Niterói, Brazil, ${ }^{2}$ MARUM-Center for Marine Environmental Sciences, University of Bremen, Bremen, Germany, ${ }^{3}$ Programa de Pós-Graduação Dinâmica dos Oceanos e da Terra, Universidade Federal Fluminense, Niterói, Brazil, ${ }^{4}$ Alfred Wegener Institute for Polar and Marine Research, Bremerhaven, Germany, ${ }^{5}$ School of Arts, Sciences and Humanities, University of São Paulo, São Paulo, Brazil

Tropical precipitation patterns will most likely be altered by future climate change, with major socioeconomic consequences for human populations that are highly reliant on water availability for subsistence like populations in northeastern (NE) Brazil. Socioeconomic consequences may be particularly disruptive in the occurrence of abrupt climate change. Understanding the response of tropical precipitation to abrupt climate change is a crucial task for improving future projections and devising adaptation policies. Past abrupt climate change events such as the Dansgaard-Oeschger (DO) cycles may provide relevant insights regarding the dynamics of the climate system under this type of climate change. Here we present a paleoceanographic reconstruction off NE Brazil based on geochemical analyses (stable oxygen isotopes, $\mathrm{Mg} / \mathrm{Ca}$ and $\mathrm{Ba} / \mathrm{Ca}$ ) performed in planktonic foraminifera, that focus on DO stadials of Marine Isotope Stage 5 (MIS5, 130-71 ka). Our new Ba/Ca record shows increases in fluvial discharge linked to enhanced continental precipitation over NE Brazil during DO stadials of MIS5. Tropical precipitation patterns were altered with enhanced rainfall in NE Brazil during DO stadials as a consequence of a southward displacement of the Intertropical Convergence Zone, which, in turn, was likely a response to changes in ocean heat transport and sea ice cover, as highlighted by recent climate model simulations. The results presented here provide useful information on how abrupt climate change can impact tropical rainfall, which is crucial for tropical societies in order to delineate strategies to cope with future climate change.

Keywords: intertropical convergence zone, last interglacial, Dansgaard-Oeschger cycles, northeastern Brazil, sea surface temperature

\section{INTRODUCTION}

In the tropics, human populations are highly reliant on rainfall for socioeconomic development. Thus, appropriately projecting the response of tropical precipitation to future climate is crucial since it can have widespread socioeconomic impacts, especially in semiarid regions where water resources are scarce. The semiarid region of northeastern (NE) Brazil is one of the most vulnerable regions to climate change, and global and regional climate simulations suggest that this region will be impacted 
by rainfall deficit by the end of the century (Marengo et al., 2017). Despite the importance of this topic, the projection of future tropical rainfall by numerical models is still challenging and requires improvement (Long et al., 2016). Tropical rainfall is mainly localized in a narrow band of deep convective clouds around the Equator known as the Intertropical Convergence Zone (ITCZ). It is paramount for model projections that the dynamics of ITCZ and its response to climate change is better constrained, since tropical rainfall is strongly controlled by its latitudinal migrations (Li and Xie, 2014). Thus, reconstructing precipitation changes during past abrupt climate events creates a deeper understanding on the response of the ITCZ to climate change, helping in the assessment of future impacts (McGee et al., 2014).

Dansgaard-Oeschger (DO) cycles can provide important insights regarding the response of the ITCZ to abrupt climate change (Zhang et al., 2017). DO cycles are characterized by an initial fast warming (interstadial) followed by a gradual cooling with an abrupt cooling at the end (stadial), as described by reconstructions from the high latitudes of the Northern Hemisphere (Wolff et al., 2010). Multiple triggers have been potentially linked to the occurrence of DO cycles such as changes in strength of the Atlantic meridional overturning circulation (AMOC) (Henry et al., 2016), sea ice dynamics (Li et al., 2010; Dokken et al., 2013), solar forcing (Braun et al., 2008), and even volcanism (Bay et al., 2004). Differences between DO cycles that occurred during Marine Isotope Stage 3 (MIS3) and Marine Isotope Stage 5 (MIS5) are also noteworthy. During MIS5, DO cycles lasted longer and the background climate conditions were different from MIS3, since global temperature was higher, the westerlies exhibited a more southerly position and AMOC was more stable (Buizert and Schmittner, 2015; Santos et al., 2020). These different climate backgrounds may have produced distinct responses in the tropics during MIS5, which still need to be more investigated in the literature, especially considering that abrupt events that occurred in past interglacials have the potential to occur in future warmer climates.

In the tropics, impacts of the DO cycles in rainfall patterns due to changes in the position of the ITCZ have been reported by several studies (Peterson et al., 2000; Itambi et al., 2009; Deplazes et al., 2013; Zhang et al., 2017). Weldeab et al. (2007) showed the impact of DO cycles in the West African Monsoon for the last $155 \mathrm{kyr}$, showing millennial-scale fluctuations in riverine freshwater input during the DO cycles of MIS5. However, the lack of appropriate records from the western margin of the equatorial Atlantic hinders the assessment of the hydrological impact of DO cycles of MIS5 to NE Brazilian precipitation.

In order to address this issue, we present new high-resolution stable oxygen isotopes $\left(\delta^{18} \mathrm{O}\right), \mathrm{Mg} / \mathrm{Ca}$ and $\mathrm{Ba} / \mathrm{Ca}$ from planktonic foraminifera to reconstruct past changes in surface hydrography and in riverine discharge to the western equatorial Atlantic with focus on the DO cycles of MIS5. Our data show increases in fluvial discharge off NE Brazil linked to enhanced continental precipitation during DO stadials of MIS5. These results also allowed us to investigate the most probable factors responsible for such climate fluctuations.

\section{REGIONAL SETTING}

Marine sediment core GL-1248 $\left(0^{\circ} 55.2^{\prime} \mathrm{S}, 43^{\circ} 24.1^{\prime} \mathrm{W}, 2264 \mathrm{~m}\right.$ water depth) was collected in the western equatorial Atlantic (Figure 1). The upper ocean circulation in this region is mainly influenced by the northward-flowing North Brazil Current (NBC), which originates from the bifurcation of the South Equatorial Current (SEC) around $10^{\circ} \mathrm{S}$ (Peterson and Stramma, 1991; Stramma and England, 1999). In the upper-ocean $(<100 \mathrm{~m})$, the NBC transports Tropical Water (TW), which is a warm $\left(>20^{\circ} \mathrm{C}\right)$ and saline ( $>36 \mathrm{psu}$ ) water mass (Stramma and England, 1999).

Seasonal changes in the trade wind system drive the variability of the NBC transport (Stramma et al., 1995). During austral summer and fall the ITCZ relocates southward, and the northeast (NE) trade winds strengthen (Hastenrath and Merle, 1987). This shifts the SEC bifurcation northward and weakens the NBC (Rodrigues et al., 2007). At the same time rainfall over northeastern Brazil increases, peaking from March to April. During austral winter and spring, the southeast (SE) trade winds strengthen and the ITCZ mean position is displaced northward, consequently decreasing precipitation over NE Brazil (Hastenrath and Merle, 1987).

The Parnaíba River is the main river discharging nearby our core site, and consequently the dominant source of fluvial waters and sediments to our study area under modern and past conditions (Figure 1) (e.g., Zhang et al., 2015; Sousa et al., 2021). Its main course has a length of approximately $1,400 \mathrm{~km}$ (Ramos et al., 2014), while the modern Parnaíba drainage basin area is approximately $344,000 \mathrm{~km}^{2}$ (Marques et al., 2004), the latitudinal range covered by the Parnaíba basin is approximately $2-10^{\circ} \mathrm{S}$.

\section{MATERIALS AND METHODS}

The age model of core GL-1248 is based on 12 AMS radiocarbon ages and the alignment of the Ti/Ca record of core GL-1248 to the ice $\delta^{18} \mathrm{O}$ record of the North Greenland Ice Core Project (NGRIP) using the extended Greenland Ice Core Chronology (GICC05modelext) (Andersen et al., 2004; Wolff et al., 2010). Between 6.30 and $16.66 \mathrm{~m}$ core depth, the chronology of core GL1248 was derived from the alignment of the Ti/Ca record of the core with NGRIP $\delta^{18} \mathrm{O}$ (Supplementary Figure S1). Ti/Ca fluctuations of core GL-1248 were matched with the major changes in $\delta^{18} \mathrm{O}$ from the NGRIP record, with tie-points being mostly located at the midpoint of abrupt excursions on both records. In addition, the onset of the Last Interglacial was defined by aligning the $\mathrm{Ti} / \mathrm{Ca}$ record of core GL-1248 with the Antarctic methane record from EPICA Dome C (Loulergue et al., 2008) at approximately $129 \mathrm{ka}$ on the AICC2012 time scale (Veres et al., 2013), similarly to previous studies (e.g., Govin et al., 2015). The complete age model was constructed using linear interpolation with the software clam 2.2 (Blaauw, 2010), where we used the median values of the calibrated age distributions (Supplementary Figure S2). The age model was supported by the U/Th-dated growth intervals of Brazilian speleothems during stadials (Wang 


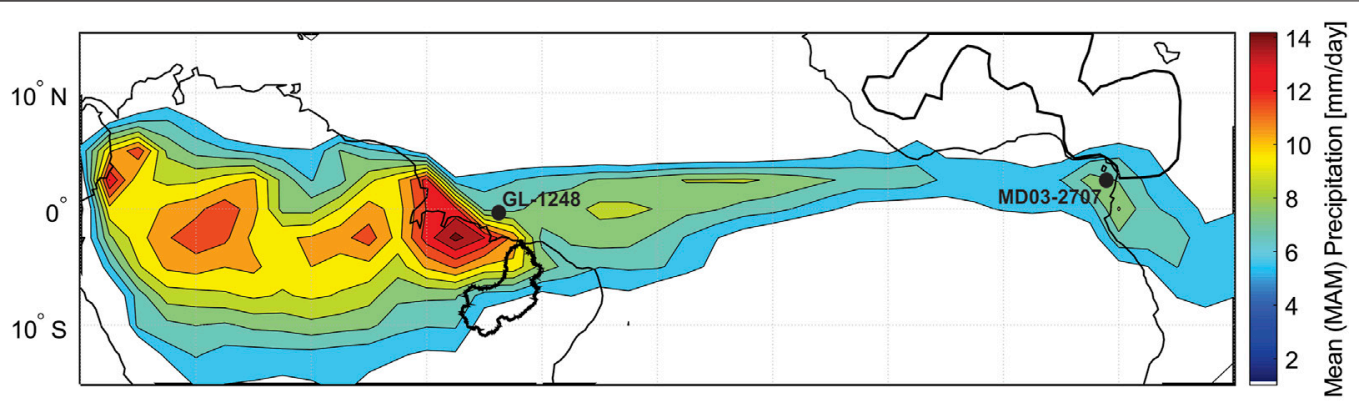

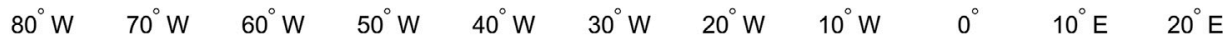

FIGURE 1 | Location of sediment cores GL-1248 (black dot) and core MD03-2707 (Weldeab et al., 2007) (black dot). Color-scale exhibits the mean precipitation (mm/day) between March and May extracted from GPCP dataset stored at NOAA/ESRL PSD (Adler et al., 2003) version 2.3. The Parnaiba River Basin and Sanaga/Niger River Basin (black contours) are displayed in the map.

et al., 2004). Since these growth intervals correspond to wet periods in northeastern Brazil, they should be coeval to the Ti/ Ca peaks in our record. Radiocarbon ages and tie-points for core GL-1248 with their respective errors are summarized in Supplementary Table S1. Further details of the age model of core GL-1248 are described in Venancio et al. (2018).

Ten tests of Globigerinoides ruber (white) $(250-355 \mu \mathrm{m})$ from core GL-1248 were analyzed for $\delta^{18} \mathrm{O}$. All tests were handpicked under a binocular microscope. Oxygen isotope analyses were performed with a Finnigan MAT 252 mass spectrometer equipped with an automated carbonate preparation device Kiel III at MARUM, University of Bremen (Germany). Isotopic results were calibrated relative to the Vienna Pee Dee Belemnite (VPDB) using the NBS19. The standard deviation of the laboratory standard was lower than $0.07 \%$ o for the measuring period. These results were previously reported in Venancio et al. (2018).

$\mathrm{Mg} / \mathrm{Ca}$ and $\mathrm{Ba} / \mathrm{Ca}$ were also analyzed in planktonic foraminifera G. ruber (white). For core GL-1248, Mg/Ca and $\mathrm{Ba} / \mathrm{Ca}$ analyses were performed on samples comprising 30 shells of $G$. ruber (white, 250-300 $\mu \mathrm{m}$ ). Samples were gently crushed and cleaned following the procedure described by Barker et al. (2003). Before dilution, samples were centrifuged for $10 \mathrm{~min}$ to exclude any remaining insoluble particles from the analyses (Groeneveld and Chiessi, 2011). The diluted solutions were analyzed with an ICP-OES Agilent Technologies 700 Series with an autosampler (ASX-520 Cetac) and a micro-nebulizer at MARUM. Each $\mathrm{Mg} / \mathrm{Ca}$ and $\mathrm{Ba} / \mathrm{Ca}$ value is averaged from three replicate runs. After every five samples one of two laboratory standards was measured to estimate the external reproducibility. Elements were measured at the following spectral lines: $\mathrm{Mg}$ $(279.553 \mathrm{~nm}), \quad \mathrm{Ca} \quad(315.887 \mathrm{~nm}), \quad \mathrm{Ba} \quad(455.403 \mathrm{~nm}), \quad \mathrm{Al}$ $(167.019 \mathrm{~nm})$ and $\mathrm{Fe}(238.204 \mathrm{~nm})$. The calibration series concentration for $\mathrm{Ca}$ ranged from 5 to $80 \mathrm{ppm}$. Each set of samples comprised four or five different dilutions, plus one blank. Only samples with $\mathrm{Al} / \mathrm{Ca}<0.5 \mathrm{mmol} / \mathrm{mol}$ were used. Contamination was also monitored by analyzing the $\mathrm{Fe} / \mathrm{Ca}$ ratios. The $\mathrm{Fe} / \mathrm{Ca}$ ratio was higher than the cut off value $(0.1 \mathrm{mmol} / \mathrm{mol})$ proposed by Barker et al. (2003). However, no correlation was found between $\mathrm{Ba} / \mathrm{Ca}$ and $\mathrm{Mg} / \mathrm{Ca}$ on the one hand with $\mathrm{Fe} / \mathrm{Ca}$ and $\mathrm{Al} / \mathrm{Ca}\left(R^{2}<0.1\right)$ on the other hand
(Supplementary Figure S3), providing no evidence for a link between the concentration of potential contamination-indicator elements ( $\mathrm{Fe}$ and $\mathrm{Al}$ ) and paleoenvironmental-indicator ratios $(\mathrm{Mg} / \mathrm{Ca}$ and $\mathrm{Ba} / \mathrm{Ca})$. The $\mathrm{Mg} / \mathrm{Ca}$ results were converted to temperatures using the $\mathrm{Mg} / \mathrm{Ca}$ temperature equation of Gray and Evans (2019) for G. ruber (white). This equation iteratively corrects for seawater salinity and carbonate chemistry effects and we followed the method that uses $\mathrm{pCO}_{2}$ to estimate seawater $\mathrm{pH}$ (Gray and Evans, 2019). Results of the $\mathrm{Mg} / \mathrm{Ca}$ ratios and the SST estimations with their standard deviations are provided in the supplementary material.

The $\delta^{18} \mathrm{O}$ of seawater $\left(\delta^{18} \mathrm{O}_{\text {sw }}\right)$ was estimated using $\mathrm{Mg} / \mathrm{Ca}$ SST and $\delta^{18} \mathrm{O}$ from $G$. ruber (white) and by applying the paleotemperature equation of Mulitza et al. (2003). A conversion constant of $0.27 \%$ was applied to convert the values from VPDB to Vienna Standard Mean Ocean Water (VSMOW) (Hut, 1987). The effect of changes in global sea level was subtracted from the $\delta^{18} \mathrm{O}_{\mathrm{sw}}$ by considering the sea level reconstruction of Grant et al. (2012) and a glacial $\delta^{18} \mathrm{O}$ increase of $0.008 \% \mathrm{~m} \mathrm{~m}^{-1}$ sea level lowering (Schrag et al., 2002) to estimate an ice-volume corrected $\delta^{18} \mathrm{O}_{\text {sw }}\left(\delta^{18} \mathrm{O}_{\text {sw-ivc }}\right) . \delta^{18} \mathrm{O}_{\text {sw }}$ estimation takes into account an uncertainty of $1.34^{\circ} \mathrm{C}$ for the $\mathrm{Mg} / \mathrm{Ca}$-SST estimations using the equation of Gray and Evans (2019), which is equivalent to $0.30 \%$ o $\delta^{18} \mathrm{O}$ change (Mulitza et al., 2003) and an analytical error for $\delta^{18} \mathrm{O}$ of $0.07 \%$. Hence, the propagated error estimated for the $\delta^{18} \mathrm{O}_{\mathrm{sw}}$ is $\pm 0.32 \%$. The $\delta^{18} \mathrm{O}_{\mathrm{sw}}$ results are provided in the supplementary material.

\section{RESULTS}

The $\delta^{18} \mathrm{O}$ of $G$. ruber (white) ranged between -1.71 and $-0.13 \%$ during MIS5 (Figure 2B). G. ruber (white) $\delta^{18} \mathrm{O}$ values show marked millennial-scale increases (up to $0.6 \%$ ), which can be linked to the main DO stadials of MIS5 (Figures 2A,B). G. ruber (white) $\mathrm{Mg} / \mathrm{Ca}$ values ranged from 3.36 to $4.77 \mathrm{mmol} / \mathrm{mol}$, which is equivalent to SST estimates of $22.48-27.79^{\circ} \mathrm{C}$ (Figure $2 \mathrm{C}$ ). In contrast with the $\delta^{18} \mathrm{O}$ values, the $\mathrm{Mg} / \mathrm{Ca}$ of $\mathrm{G}$. ruber (white) do not exhibit a well-marked millennial-scale pattern during MIS5. The $\mathrm{Ba} / \mathrm{Ca}$ values ranged from 1.25 to $4.86 \mu \mathrm{mol} / \mathrm{mol}$ 


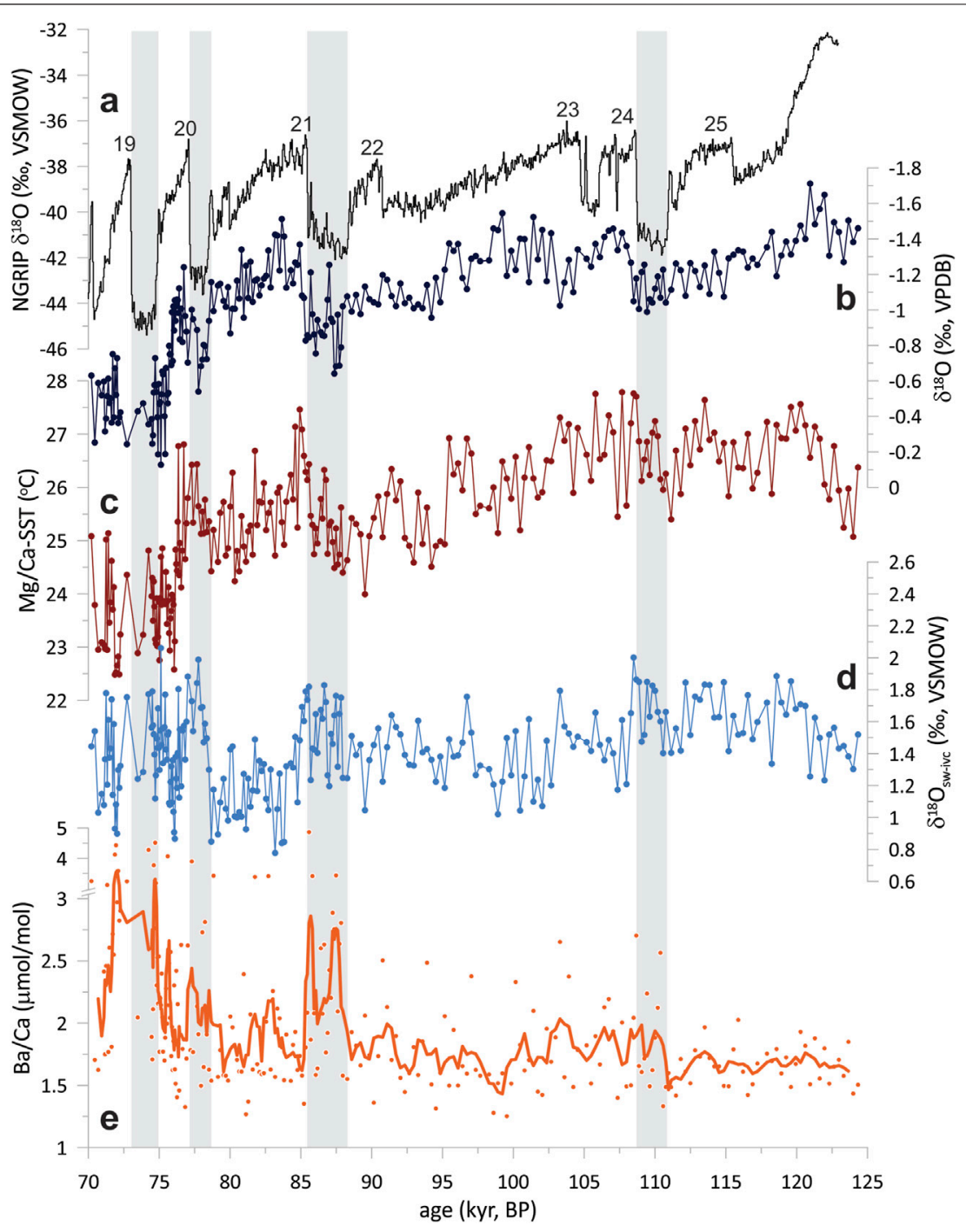

FIGURE 2 | Geochemical results from core GL-1248 compared to North Greenland Ice Core Project (NGRIP) ice stable oxygen isotope record $\left(\delta^{18} \mathrm{O}_{\text {ice }}\right)$. (A) $\delta^{18} \mathrm{O}_{\text {ice }}$ from NGRIP on the GICC05modelext time scale (Andersen e al., 2004; Wolff et al., 2010; black line). (B) $\delta^{18} \mathrm{O}$ of Globigerinoides ruber (white) from core GL-1248 (blue line). (C) Sea surface temperature (SST) derived from $\mathrm{Mg} / \mathrm{Ca}$ of Globigerinoides ruber (white) from core GL-1248 (red line). (D) ice volume corrected $\delta^{18} \mathrm{O}$ of seawater $\left(\delta^{18} \mathrm{O}_{\text {sw-ivc}}\right.$ ) of Globigerinoides ruber (white) from core GL-1248 (light blue line). (E) Ba/Ca ratios of Globigerinoides ruber (white) from core GL-1248 (orange line). Ba/ Ca results are shown as 5 -point running-average of the data points. Dansgaard-Oeschger (DO) stadials are marked by the grey bars, and the number of the DO cycles is exhibited in panel a.

(Figure 2D). Despite the more scattered data, Ba/Ca of G. ruber (white) values show millennial-scale increases (up to $3.3 \mu \mathrm{mol} /$ mol) during most of the DO stadials of MIS5 (Figure 2D). The $\delta^{18} \mathrm{O}_{\text {sw-ivc }}$ exhibited values ranging from 0.78 to $2.06 \%$ and similarly to the $\delta^{18} \mathrm{O}$ values showed a well-marked millennialscale pattern during MIS5 (Figure 2E), with increases in $\delta^{18} \mathrm{O}_{\text {sw- }}$ ivc values (up to $1.2 \%$ ) during DO stadials. Besides the millennialscale variations across MIS5, our results show a marked increase (decrease) in mean values of $\delta^{18} \mathrm{O}(\mathrm{Mg} / \mathrm{Ca}-\mathrm{SST})$ of $\mathrm{G}$. ruber (white) at $76 \mathrm{ka}$. Mean values of $\delta^{18} \mathrm{O}$ and $\mathrm{Mg} / \mathrm{Ca}-\mathrm{SST}$ of $\mathrm{G}$. ruber (white) subsequent to $76 \mathrm{ka}$ were $-0.51 \%$ and $23.66^{\circ} \mathrm{C}$, respectively. Prior to $76 \mathrm{ka}$ the $\delta^{18} \mathrm{O}$ and $\mathrm{Mg} / \mathrm{Ca}-\mathrm{SST}$ of $\mathrm{G}$. ruber (white) were $-1.15 \%$ and $25.86^{\circ} \mathrm{C}$, respectively.

\section{DISCUSSION}

Tropical MIS5 millennial-scale changes in sea surface salinity (SSS) linked to variations in riverine runoff were previously reported for the Gulf of Guinea (Weldeab et al., 2007). The authors showed well-marked decreases in $\mathrm{Ba} / \mathrm{Ca}$ and increases in $\delta^{18} \mathrm{O}_{\text {sw }}$ records from core MD03-2707 during DO stadials of MIS5, both proxies suggesting increase in SSS (Figures 3D,E). Their results indicate a reduction in precipitation over the catchments of the Niger and Sanaga rivers $\left(3-25^{\circ} \mathrm{N}\right)$ during the DO stadials of MIS5, which was linked to reduced West African monsoonal rainfall (Weldeab et al., 2007). A comparison between our $\mathrm{Ba} / \mathrm{Ca}$ record from $\mathrm{GL}-1248$ with the $\mathrm{Ba} / \mathrm{Ca}$ from 


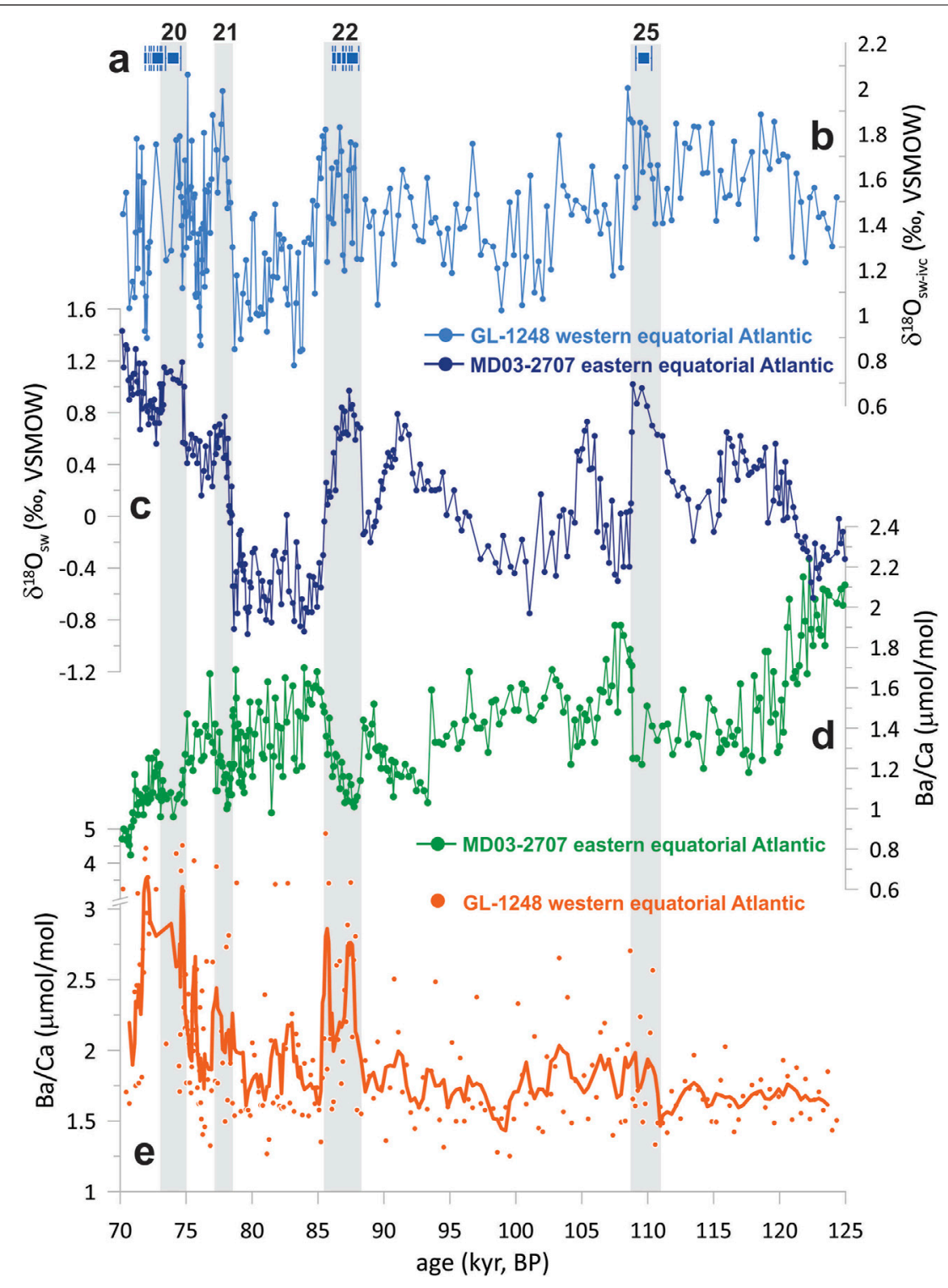

FIGURE 3 | Comparison of hydrological changes between eastern and western equatorial Atlantic. (A) Growth intervals of speleothem and travertine from northeastern Brazil with their respective dating errors (Wang et al., 2004, blue squares). (B) $\delta^{18} \mathrm{O}_{\text {sw-ivc }}$ of Globigerinoides ruber (white) from core $\mathrm{GL}$-1248 (light blue line). (C) $\delta^{18} \mathrm{O}_{\text {sw }}$ of Globigerinoides ruber (pink) from core MD03-2707 (dark blue line, Weldeab et al., 2007). (D) Ba/Ca ratios of Globigerinoides ruber (pink) from core MD032707 (green line, Weldeab et al., 2007). (E) Ba/Ca ratios of Globigerinoides ruber (white) from core GL-1248 (orange line). Ba/Ca results are shown as 5-point running-average of the data points. Dansgaard-Oeschger stadials are marked by the grey bars.

core MD03-2707 (Figure 3) shows an opposite pattern of both records during DO stadials of MIS5, with core GL-1248 showing increases in $\mathrm{Ba} / \mathrm{Ca}$ while core MD03-2707 shows decrease in $\mathrm{Ba} /$ $\mathrm{Ca}$ values. However, the $\delta^{18} \mathrm{O}_{\mathrm{sw}}$ record from core GL-1248 (Figure 3) shows increased values during DO stadials, similarly to the record of core MD03-2707.

The increases in $\mathrm{Ba} / \mathrm{Ca}$ in core GL-1248 indicate enhanced riverine runoff during DO stadials of MIS5 (Figure 3). This suggestion agrees with data from Wang et al. (2004), which shows speleothem growth phases linked to high rainfall periods over northeastern Brazil (Figure 3). Thus, the enhanced runoff during DO stadials was probably due to enhanced continental precipitation over the Parnaiba catchment area. $\mathrm{Fe} / \mathrm{K}$ and $\mathrm{Fe} /$ $\mathrm{Ca}$ ratios records from core GL-1248, as well as from a nearby core (CDH-86; Nace et al., 2014), confirm the occurrence of intense chemical weathering and terrestrial input, respectively (Fadina et al., 2019; Sousa et al., 2021; Piacsek et al., 2021) (Supplementary Figure S4). Concomitantly, Ti/Ca values from core MD99-2198 (Tobago Basin), as molybdenum (Mo) values from core MD03-2622 (Cariaco Basin), decrease during DO stadials, indicating a reduction in terrigenous contribution at those locations (Zhuravleva et al., 2021; Gibson and Peterson, 2014). The observed increases in $\delta^{18} \mathrm{O}_{\text {sw }}$ in GL-1248 (Figure 3) were probably caused by distinct ocean-atmosphere processes 
that influenced the $\delta^{18} \mathrm{O}_{\text {sw }}$ signal, but not the $\mathrm{Ba} / \mathrm{Ca}$ values. Bahr et al. (2013) explained this divergence between the $\mathrm{Ba} / \mathrm{Ca}$ and $\delta^{18} \mathrm{O}_{\mathrm{sw}}$ by showing that these proxies have different mixing behaviors, it is conservative for $\delta^{18} \mathrm{O}_{\mathrm{sw}}$ and non-linear for $\mathrm{Ba} /$ $\mathrm{Ca}$. This means that the signal of $\delta^{18} \mathrm{O}_{\mathrm{sw}}$ is more affected by the conservative mixing of different water end-members (e.g. freshwater or ocean water masses), while $\mathrm{Ba}$ can be removed or added into water by geochemical processes during mixing. For example, removal of adsorbed Ba by ion exchange during mixing of river and marine waters can introduce dissolved $\mathrm{Ba}$ into seawater (Hanor and Chan, 1977). Using core-top samples from the western tropical Atlantic, Bahr et al. (2013) showed that high $\mathrm{Ba} / \mathrm{Ca}$ ratios in foraminiferal calcite can be recorded without any change in the $\delta^{18} \mathrm{O}_{\text {sw. }}$.

The intriguing divergence between $\mathrm{Ba} / \mathrm{Ca}$ and $\delta^{18} \mathrm{O}_{\mathrm{sw}}$ signals in the western tropical Atlantic during MIS5 was also observed for the last termination. Venancio et al. (2020) showed that $\mathrm{Ba} / \mathrm{Ca}$ of core GL-1248 increased during the Younger Dryas (YD), while several $\delta^{18} \mathrm{O}_{\mathrm{sw}}$ records for the western tropical Atlantic showed increases or no clear changes in the values, with the exception of the record from core CDH-86 (Nace et al., 2014) that showed a decrease in $\delta^{18} \mathrm{O}_{\mathrm{sw}}$ during the YD. The increases in $\delta^{18} \mathrm{O}_{\mathrm{sw}}$ in the western tropical Atlantic were attributed to a reduction of the cross-equatorial transport of saline waters due to a weakening of the NBC linked to slowdowns of the AMOC during the YD (Weldeab et al., 2006; Venancio et al., 2020). The results from our study and previous published works (Bahr et al., 2013; Venancio et al., 2020) show that $\mathrm{Ba} / \mathrm{Ca}$ is a reliable proxy to track past changes fluvial discharge. $\delta^{18} \mathrm{O}_{\mathrm{sw}}$ gives a signal that is the result of freshwater discharge and ocean-atmosphere processes. The enhanced freshwater discharge during DO stadials of MIS5, as revealed by the $\mathrm{Ba} / \mathrm{Ca}$ record, should have been translated into a decrease in $\delta^{18} \mathrm{O}_{\mathrm{sw}}$ at our site. However, we observe increases in $\delta^{18} \mathrm{O}_{\mathrm{sw}}$, which is probably due to oceanic processes that are driving the signal in an opposite direction. The most plausible explanation is that salinity increased off northeastern Brazil during DO stadials of MIS5 as a result of salt accumulation due to the weakening of the NBC, which is a coherent scenario considering slowdowns of the AMOC during these stadials (Böhm et al., 2015) and the coupling between AMOC and NBC dynamics (Weldeab et al., 2006). This explains the increases in $\delta^{18} \mathrm{O}_{\mathrm{sw}}$ in core GL-1248 during DO stadials of MIS5, and shows that freshwater discharge influence was surpassed by oceanic processes, which were recorded in the $\delta^{18} \mathrm{O}_{\mathrm{sw}}$ record at our site.

The antiphase rainfall responses to DO stadials of MIS5 between West Africa and northeastern Brazil suggests a common climatic mechanism. Since precipitation in both regions are influenced by the dynamics of the ITCZ, it is plausible that changes in ITCZ position caused changes in continental precipitation over the Parnaiba and Sanaga/Niger basins. Southward shifts of the ITCZ have been reported to occur during DO stadials, impacting rainfall patterns over the Cariaco Basin (Peterson et al., 2000; Deplazes et al., 2013; Gibson and Peterson, 2014), Tobago Basin (Zhuravleva et al., 2021), northeastern Brazil (Jaeschke et al., 2007; Zhang et al., 2017) and West Africa (Tjallingii et al., 2008; Itambi et al., 2009). Regarding the DO stadials of MIS5, the regional picture that emerges for tropical South America is a reduction in precipitation and runoff in Cariaco and Tobago Basins (Gibson and Peterson, 2014; Zhuravleva et al., 2021), with a concomitantly enhanced rainfall and fluvial discharge off northeastern Brazil, as shown by this study. Moreover, particularly in these regions located in South America, as in West Africa, local rainfall correlates with zonal mean ITCZ changes (Roberts et al., 2017) and might be used to evaluate large scale patterns of tropical rainfall. However, the main climatic forcing driving tropical rainfall changes linked to ITCZ shifts during DO cycles, especially during MIS5, remains elusive.

Wang et al. (2004) observed a strong correlation between speleothem growth phases and high austral autumn insolation at $10^{\circ} \mathrm{S}$. This led the authors to conclude that additionally to the response of the ITCZ to the thermal bipolar seesaw (Crowley, 1992; Stocker and Johnsen, 2003), enhanced rainfall over northeastern Brazil was related to southward shifts of the ITCZ due to increased land/sea thermal contrast modulated by precessional forcing. However, although the precessional mechanism explains the enhanced rainfall during DO stadials 25 and 22, it does not explain DO stadials 21 and 20. During DO stadials 21 and 20, high $\mathrm{Ba} / \mathrm{Ca}$ values off northeastern Brazil and low $\mathrm{Ba} / \mathrm{Ca}$ off West Africa are observed (Figures 3, 4). Thus, although precessional forcing may have modulated tropical rainfall related to the ITCZ dynamics during the past (e.g., Nascimento et al., 2021), it cannot be the sole factor that explains these proxy records during DO stadials of MIS5.

Utida et al. (2019) suggested that past ITCZ shifts were modulated by tropical South Atlantic (TSA) SST, where positive TSA-SST anomalies led to southward displacements of the annual-mean position of the ITCZ and enhanced precipitation over northeastern Brazil. This is consistent with previous interpretations which suggested a major role of the tropical forcing over ITCZ excursions (e.g., Xie and Carton, 2004). However, TSA-SST records from cores GL-1248 and MD03-2707 do not show well-marked increases during DO stadials (Figure 4). This indicates that TSA-SST probably played a secondary role regarding southward displacements of the annual-mean position of the ITCZ during DO stadials of MIS5. Thus, it is plausible to assume that extratropical forcing might be the dominant factor linked to ITCZ shifts, in line with recent studies (Schneider et al., 2014; Seo et al., 2014; Mulitza et al., 2017; Kang et al., 2018; Kang, 2020).

Recently, the study of Santos et al. (2020) suggested that the subtropical South Atlantic acted as a heat reservoir in periods of weakened AMOC during DO stadials of MIS 5. By using geochemical analyses performed in foraminifera recording the permanent thermocline from the western South Atlantic, the authors showed subsurface temperature and salinity increases during these events, which may also hold for the sea surface but can be hampered by local ocean-atmosphere feedbacks (Venancio et al., 2020). Such heat accumulation in the subtropics due to a weakened AMOC probably influenced the Hadley cell circulation and contributed to a southward ITCZ displacement (Frierson et al., 2013; Mulitza et al., 2017). Warming of one hemisphere leads to an ITCZ shift in order to balance the oceanic heating via cross-equatorial atmospheric energy transport (Donohoe et al., 2013; Marshall et al., 2014). 


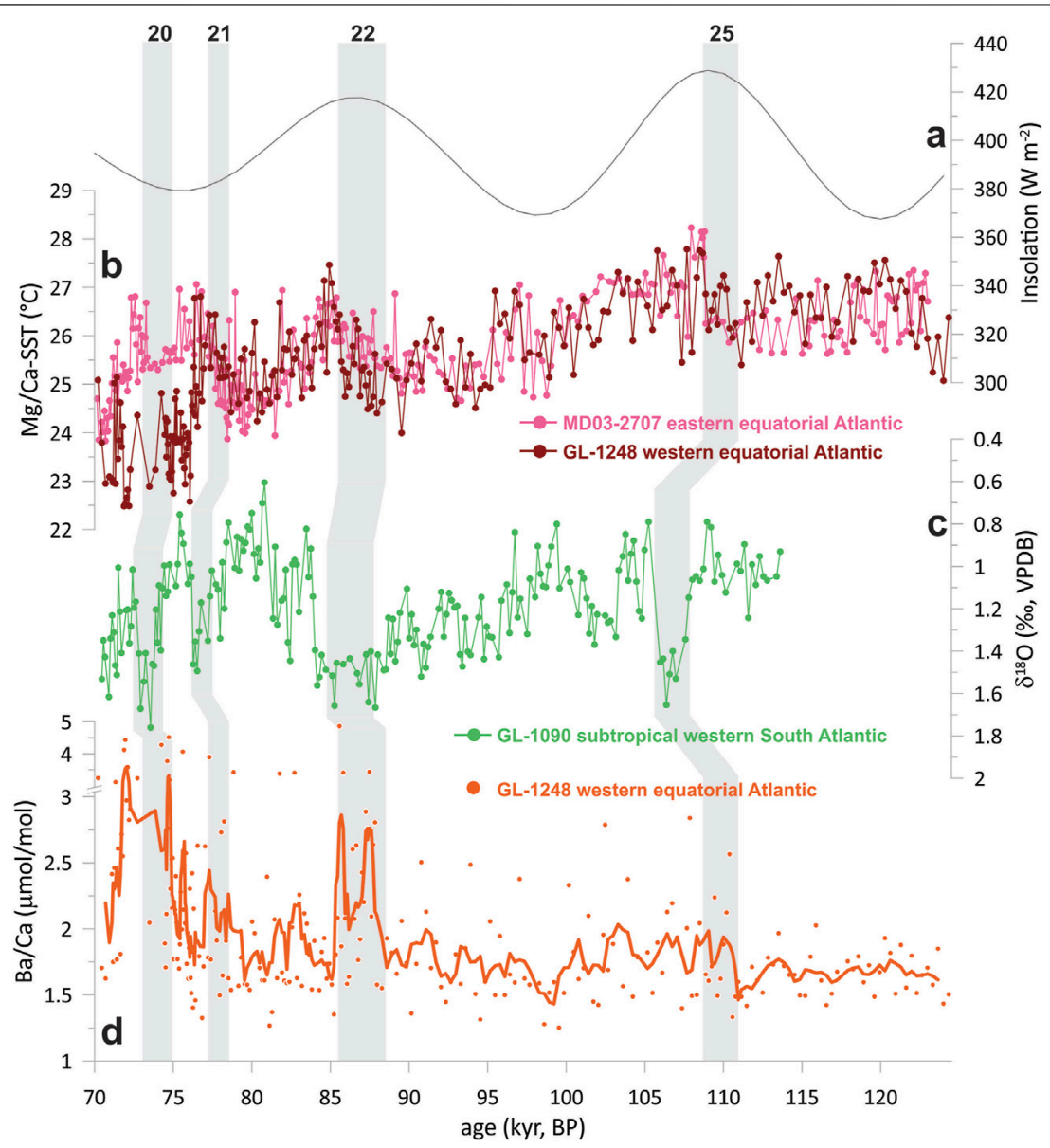

FIGURE 4 | Climatic forcings related to the tropical climate response to Dansgaard-Oeschger stadials. (A) Austral autumn insolation at $10^{\circ} \mathrm{S}$ (grey line, Berger and Loutre, 1991). (B) Sea surface temperature (SST) derived from Mg/Ca of Globigerinoides ruber (white) from core GL-1248 (red line) and from Mg/Ca of Globigerinoides ruber (pink) from core MD03-2707 (pink line). (C) $\delta^{18} \mathrm{O}$ of Globorotalia inflata from core GL-1090 (light green line, Santos et al., 2020). (D) Ba/Ca ratios of Globigerinoides ruber (white) from core GL-1248 (orange line). Ba/Ca results are shown as running-average of the data points. Dansgaard-Oeschger stadials are marked by the grey bars.

Such ITCZ responses to cross-equatorial energy transport linked to AMOC changes were highlighted as the main factor that determines the magnitude of ITCZ shifts, especially if hemispherically asymmetric solar forcing is concentrated at higher latitudes (Yu and Pritchard, 2019). Except for DO stadial 25, periods with high $\mathrm{Ba} / \mathrm{Ca}$ in core GL-1248 seem to coincide with the observed changes in South Atlantic subtropical heat content, exemplified by permanent thermocline $\delta^{18} \mathrm{O}$ from core GL-1090 (Figure 4) (Santos et al., 2020). This indicates that such atmospheric adjustments due to variations in ocean heat transport contributes to the understanding of past changes in tropical precipitation.

Climate model simulations show that sea ice cover may also influence the position of the ITCZ (Chiang and Bitz, 2005). Advances in Northern Hemisphere sea ice cause cooling in high northern latitudes, which propagates towards the equator via ocean-atmosphere feedbacks and results in a southward shift of the ITCZ (Chiang and Bitz, 2005). Changes in Northern Hemisphere sea ice are also viewed as one of the main mechanisms linked to DO cycles (Li et al., 2010; Dokken et al., 2013). Thus, the southward displacements of ITCZ during DO stadials of MIS5 revealed by our proxy records may be caused by southward expansion of sea ice in high northern latitudes. Indeed, Rama-Corredor et al. (2015) show abrupt decreases in tropical North Atlantic SST during DO stadials of MIS5 as a consequence of rapid transmission of climate signals from high to low latitudes. This is also corroborated by the results from Deplazes et al. (2013), which show that the ITCZ system responds primarily to changes in Northern Hemisphere temperatures.

The SST reconstruction from core GL-1248, together with other tropical SST records, discarded a major role of TSA-SST as a trigger of rainfall changes during DO stadials of MIS5. Also, autumn insolation cannot be the sole factor controlling ITCZ displacements during MIS5, since our $\mathrm{Ba} / \mathrm{Ca}$ record and XRF data for core GL-1248 do not display a precessional pace, and autumn insolation was low during DO stadials 21 and 20 , while $\mathrm{Ba} / \mathrm{Ca}$ exhibited high values. Therefore, our results indicate that 
extratropical forcing related mainly to interhemispheric ocean heat transport and sea ice cover is probably the key factor influencing tropical rainfall changes due to ITCZ shifts during DO cycles of MIS5. Both processes impact ocean thermal gradients, which may be the main cause of the ITCZ displacements. This is in line with climate model simulations showing that tropical rainfall cannot be explained only by ocean heat transport or changes in sea ice extent (Roberts and Hopcroft, 2020). It is most probable that a combination of both factors is important in order to promote North Atlantic SST changes and consequently influence ITCZ position (Roberts and Hopcroft, 2020). Thus, tropical rainfall changes during DO stadials of MIS5 were mainly the result of meridional displacements of the ITCZ position due to extratropical perturbations. This might have been caused by ocean-atmosphere feedbacks (Chiang and Bitz, 2005) and/or changes in the energy budget (Marshall et al., 2014).

\section{CONCLUSION}

We reconstructed ocean surface conditions of the western equatorial Atlantic based on the $\delta^{18} \mathrm{O}, \mathrm{Mg} / \mathrm{Ca}$ and $\mathrm{Ba} / \mathrm{Ca}$ ratios of planktonic foraminifera $G$. ruber (white) in order to investigate ocean-atmosphere changes during the DO stadials of MIS5. Our $\mathrm{Ba} / \mathrm{Ca}$ record shows higher fluvial discharge during DO stadials, indicating enhanced rainfall over northeastern Brazil. The comparison with a $\mathrm{Ba} / \mathrm{Ca}$ record from the eastern tropical Atlantic revealed opposite trends in rainfall between the West African monsoon domain and northern northeastern Brazil during DO stadials of MIS5. These opposite trends were probably caused by fluctuations in the latitudinal position of the ITCZ. We suggest that the main causes for these ITCZ displacements are changes in ocean heat transport and Northern Hemisphere sea ice cover. Our interpretations are in line with recent climate model simulations, which suggest that both factors influence the position of the ITCZ and tropical rainfall during abrupt climate events. In this sense, future changes in the meridional overturning circulation and sea ice cover, which are likely to occur under global warming, will probably alter tropical rainfall patterns, with major consequences to tropical societies. Our results provide an in-depth understanding of the dynamics of the climate system during abrupt climate change events, and highlight the need to improve strategies for mitigation and adaptation to future climate change, especially in semiarid regions which present high vulnerability to changes in the hydrological cycle.

\section{REFERENCES}

Adler, R. F., Huffman, G. J., Chang, A., Ferraro, R., Xie, P.-P., Janowiak, J., et al. (2003). The Version-2 Global Precipitation Climatology Project (GPCP) Monthly Precipitation Analysis (1979-Present). J. Hydrometeorol. 4, 1147-1167. doi:10.1175/1525-7541(2003)004<1147:TVGPCP > 2.0.CO;2

Andersen, K. K., Azuma, N., Barnola, J. M., Bigler, M., Biscaye, P., Caillon, N., et al. (2004). High-resolution Record of Northern Hemisphere Climate Extending into the Last Interglacial Period. Nature 431, 147-151. doi:10. 1038 /nature 02805

\section{DATA AVAILABILITY STATEMENT}

The datasets presented in this study can be found in online repositories. The names of the repository/repositories and accession number(s) can be found below: Mendeley Data (http://dx.doi.org/10.17632/xdrpswbhnh.2).

\section{AUTHOR CONTRIBUTIONS}

IV designed the study, analyzed the data and wrote the manuscript with contribution from all authors. All authors contributed to the interpretation of results. All authors commented on and edited the manuscript.

\section{FUNDING}

This study was supported by the CAPES-ASpECTO project (grant 88887.091731/2014-01) CNPq-Aspecto (grant 429767/2018-8), CAPES-PRINT CLIMATE Project (grant 88887.310301/2018-00) and $\mathrm{CNPq}$ Project RAiN (grant 406322/2018-0). IMV acknowledges the scholarship from CAPES (grant 88881.512929/ 2020-01) and the Alexander von Humboldt Foundation. RAN acknowledges the scholarship from CAPES (grant 88887.176103/ 2018-00). CMC acknowledges the financial support from FAPESP (grants 2018/15123-4 and 2019/24349-9), CAPES (grants 564/2015 and 88881.313535/2019-01), CNPq (grant 312458/2020-7), and the Alexander von Humboldt Foundation. ALSA is a senior scholar CNPq (grant 302521/2017-8).

\section{ACKNOWLEDGMENTS}

We thank Petrobras for providing the sediment core used in this study. We also acknowledge the partial support from the Coordenação de Aperfeiçoamento de Pessoal de Nível Superior-Brasil (CAPES)-Finance Code 001.

\section{SUPPLEMENTARY MATERIAL}

The Supplementary Material for this article can be found online at: https:/www.frontiersin.org/articles/10.3389/feart.2022.826993/ full\#supplementary-material

Bahr, A., Schönfeld, J., Hoffmann, J., Voigt, S., Aurahs, R., Kucera, M., et al. (2013). Comparison of $\mathrm{Ba} / \mathrm{Ca}$ and $\delta$ OWATER18 as Freshwater Proxies: A MultiSpecies Core-Top Study on Planktonic Foraminifera from the Vicinity of the Orinoco River Mouth. Earth Planet. Sci. Lett. 383, 45-57. doi:10.1016/j.epsl. 2013.09.036

Barker, S., Greaves, M., and Elderfield, H. (2003). A Study of Cleaning Procedures Used for Foraminiferal Mg/Ca Paleothermometry. Geochem. Geophys. Geosyst. 4, a-n. doi:10.1029/2003GC000559

Bay, R. C., Bramall, N., and Price, P. B. (2004). Bipolar Correlation of Volcanism with Millennial Climate Change. Proc. Natl. Acad. Sci. 101, 6341-6345. doi:10. 1073/pnas.0400323101 
Berger, A., and Loutre, M. F. (1991). Insolation Values for the Climate of the Last 10 Million Years. Quat. Sci. Rev. 10, 297-317. doi:10.1016/0277-3791(91) 90033-Q

Blaauw, M. (2010). Methods and Code for 'Classical' Age-Modelling of Radiocarbon Sequences. Quat. Geochronol. 5, 512-518. doi:10.1016/j.quageo. 2010.01.002

Böhm, E., Lippold, J., Gutjahr, M., Frank, M., Blaser, P., Antz, B., et al. (2015). Strong and Deep Atlantic Meridional Overturning Circulation during the Last Glacial Cycle. Nature 517, 73-76. doi:10.1038/nature14059

Braun, H., Ditlevsen, P., and Chialvo, D. R. (2008). Solar Forced DansgaardOeschger Events and Their Phase Relation with Solar Proxies. Geophys. Res. Lett. 35. doi:10.1029/2008GL033414

Buizert, C., and Schmittner, A. (2015). Southern Ocean Control of Glacial AMOC Stability and Dansgaard-Oeschger Interstadial Duration. Paleoceanography 30, 1595-1612. doi:10.1002/2015PA002795

Chiang, J. C. H., and Bitz, C. M. (2005). Influence of High Latitude Ice Cover on the marine Intertropical Convergence Zone. Clim. Dyn. 25, 477-496. doi:10.1007/ s00382-005-0040-5

Crowley, T. J. (1992). North Atlantic Deep Water Cools the Southern Hemisphere. Paleoceanography 7, 489-497. doi:10.1029/92PA01058

de Sousa, T. A., Venancio, I. M., Valeriano, C. d. M., Heilbron, M., Weitzel Dias Carneiro, M. T., Mane, M. A., et al. (2021). Changes in Sedimentary Provenance and Climate off the Coast of Northeast Brazil since the Last Interglacial. Mar. Geology. 435, 106454. doi:10.1016/j.margeo.2021.106454

Deplazes, G., Lückge, A., Peterson, L. C., Timmermann, A., Hamann, Y., Hughen, K. A., et al. (2013). Links between Tropical Rainfall and North Atlantic Climate during the Last Glacial Period. Nat. Geosci 6, 213-217. doi:10.1038/ngeo1712

Dokken, T. M., Nisancioglu, K. H., Li, C., Battisti, D. S., and Kissel, C. (2013). Dansgaard-Oeschger Cycles: Interactions between Ocean and Sea Ice Intrinsic to the Nordic Seas. Paleoceanography 28, 491-502. doi:10.1002/palo.20042

Donohoe, A., Marshall, J., Ferreira, D., and Mcgee, D. (2013). The Relationship between ITCZ Location and Cross-Equatorial Atmospheric Heat Transport: From the Seasonal Cycle to the Last Glacial Maximum. J. Clim. 26, 3597-3618. doi:10.1175/JCLI-D-12-00467.1

Fadina, O. A., Venancio, I. M., Belem, A., Silveira, C. S., Bertagnolli, D. d. C., SilvaFilho, E. V., et al. (2019). Paleoclimatic Controls on Mercury Deposition in Northeast Brazil since the Last Interglacial. Quat. Sci. Rev. 221, 105869. doi:10. 1016/j.quascirev.2019.105869

Frierson, D. M. W., Hwang, Y.-T., Fučkar, N. S., Seager, R., Kang, S. M., Donohoe, A., et al. (2013). Contribution of Ocean Overturning Circulation to Tropical Rainfall Peak in the Northern Hemisphere. Nat. Geosci 6, 940-944. doi:10.1038/ ngeo1987

Gibson, K. A., and Peterson, L. C. (2014). A 0.6 Million Year Record of MillennialScale Climate Variability in the Tropics. Geophys. Res. Lett. 41, 969-975. doi:10. 1002/2013GL058846

Govin, A., Capron, E., Tzedakis, P. C., Verheyden, S., Ghaleb, B., and HillaireMarcel, C. (2015). Sequence of Events From the Onset to the Demise of the Last Interglacial: Evaluating Strengths and Limitations of Chronologies used in Climatic Archives. Quat. Sci. Rev. 129, 1-36. doi:10.1016/j.quascirev.2015. 09.018

Grant, K. M., Rohling, E. J., Bar-Matthews, M., Ayalon, A., Medina-Elizalde, M., Ramsey, C. B., et al. (2012). Rapid Coupling between Ice Volume and Polar Temperature over the Past 150,000 Years. Nature 491, 744-747. doi:10.1038/naturel1593

Gray, W. R., and Evans, D. (2019). Nonthermal Influences on Mg/Ca in Planktonic Foraminifera: A Review of Culture Studies and Application to the Last Glacial Maximum. Paleoceanography and Paleoclimatology 34, 306-315. doi:10.1029/ 2018PA003517

Groeneveld, J., and Chiessi, C. M. (2011). Mg/Ca ofGloborotalia Inflataas a Recorder of Permanent Thermocline Temperatures in the South Atlantic. Paleoceanography 26, a-n. doi:10.1029/2010PA001940

Hanor, J. S., and Chan, L.-H. (1977). Non-conservative Behavior of Barium during Mixing of Mississippi River and Gulf of Mexico Waters. Earth Planet. Sci. Lett. 37, 242-250. doi:10.1016/0012-821X(77)90169-8

Hastenrath, S., and Merle, J. (1987). Annual Cycle of Subsurface Thermal Structure in the Tropical Atlantic Ocean. J. Phys. Oceanogr. 17, 1518-1538. doi:10.1175/ 1520-0485(1987)017<1518:acosts>2.0.co;2

Henry, L. G., McManus, J. F., Curry, W. B., Roberts, N. L., Piotrowski, A. M., and Keigwin, L. D. (2016). North Atlantic Ocean Circulation and Abrupt Climate
Change during the Last Glaciation. Science 353, 470-474. doi:10.1126/science. aaf5529

Hut, G. (1987). "Consultants' Group Meeting on Stable Isotope Reference Samples for Geochemical and Hydrological Investigations," in Consultants' Group Meeting on Stable Isotope Reference Samples for Geochemical and Hydrological Investigations (Vienna, Austria: International Atomic Energy Agency). Available from: http://inis.iaea.org/search/search.aspx?orig_q=RN: 18075746.

Itambi, A. C., von Dobeneck, T., Mulitza, S., Bickert, T., and Heslop, D. (2009). Millennial-scale Northwest African Droughts Related to Heinrich Events and Dansgaard-Oeschger Cycles: Evidence in marine Sediments from Offshore Senegal. Paleoceanography 24, a-n. doi:10.1029/ 2007PA001570

Jaeschke, A., Rühlemann, C., Arz, H., Heil, G., and Lohmann, G. (2007). Coupling of Millennial-Scale Changes in Sea Surface Temperature and Precipitation off Northeastern Brazil with High-Latitude Climate Shifts during the Last Glacial Period. Paleoceanography 22, a-n. doi:10.1029/2006PA001391

Kang, S. M. (2020). Extratropical Influence on the Tropical Rainfall Distribution. Curr. Clim. Change Rep. 6, 24-36. doi:10.1007/s40641-020-00154-y

Kang, S. M., Shin, Y., and Xie, S.-P. (2018). Extratropical Forcing and Tropical Rainfall Distribution: Energetics Framework and Ocean Ekman Advection. Npj Clim. Atmos. Sci. 1, 20172. doi:10.1038/s41612-017-0004-6

Li, C., Battisti, D. S., and Bitz, C. M. (2010). Can North Atlantic Sea Ice Anomalies Account for Dansgaard-Oeschger Climate Signals. J. Clim. 23, 5457-5475. doi:10.1175/2010JCLI3409.1

Li, G., and Xie, S.-P. (2014). Tropical Biases in CMIP5 Multimodel Ensemble: The Excessive Equatorial Pacific Cold Tongue and Double ITCZ Problems*. J. Clim. 27, 1765-1780. doi:10.1175/JCLI-D-13-00337.1

Long, S.-M., Xie, S.-P., and Liu, W. (2016). Uncertainty in Tropical Rainfall Projections: Atmospheric Circulation Effect and the Ocean Coupling. J. Clim. 29, 2671-2687. doi:10.1175/jcli-d-15-0601.1

Loulergue, L., Schilt, A., Spahni, R., Masson-Delmotte, V., Blunier, T., Lemieux, B., et al. (2008). Orbital and Millennial-Scale Features of Atmospheric CH4 Over the Past 800,000 Year. Nature 453, 383-386. doi:10.1038/nature06950

Marengo, J. A., Torres, R. R., and Alves, L. M. (2017). Drought in Northeast Brazilpast, Present, and Future. Theor. Appl. Climatol. 129, 1189-1200. doi:10.1007/ s00704-016-1840-8

Marques, M., da Costa, M. F., Mayorga, M. I. d. O., and Pinheiro, P. R. C. (2004). Water Environments: Anthropogenic Pressures and Ecosystem Changes in the Atlantic Drainage Basins of Brazil. AMBIO: A J. Hum. Environ. 33, 68-77. doi:10.1579/0044-7447-33.1.68

Marshall, J., Donohoe, A., Ferreira, D., and McGee, D. (2014). The Ocean's Role in Setting the Mean Position of the Inter-tropical Convergence Zone. Clim. Dyn. 42, 1967-1979. doi:10.1007/s00382-013-1767-z

McGee, D., Donohoe, A., Marshall, J., and Ferreira, D. (2014). Changes in ITCZ Location and Cross-Equatorial Heat Transport at the Last Glacial Maximum, Heinrich Stadial 1, and the Mid-holocene. Earth Planet. Sci. Lett. 390, 69-79. doi:10.1016/j.epsl.2013.12.043

Mulitza, S., Boltovskoy, D., Donner, B., Meggers, H., Paul, A., and Wefer, G. (2003). Temperature: $\delta 18 \mathrm{O}$ Relationships of Planktonic Foraminifera Collected from Surface Waters. Palaeogeogr. Palaeoclimatol. Palaeoecol. 202, 143-152. doi:10. 1016/S0031-0182(03)00633-3

Mulitza, S., Chiessi, C. M., Schefuß, E., Lippold, J., Wichmann, D., Antz, B., et al. (2017). Synchronous and Proportional Deglacial Changes in Atlantic Meridional Overturning and Northeast Brazilian Precipitation. Paleoceanography 32, 622X-633. doi:10.1002/2017PA003084

Nace, T. E., Baker, P. A., Dwyer, G. S., Silva, C. G., Rigsby, C. A., Burns, S. J., et al. (2014). The Role of North Brazil Current Transport in the Paleoclimate of the Brazilian Nordeste Margin and Paleoceanography of the Western Tropical Atlantic during the Late Quaternary. Palaeogeogr. Palaeoclimatol. Palaeoecol. 415, 3-13. doi:10.1016/j.palaeo.2014.05.030

Nascimento, R. A., Venancio, I. M., Chiessi, C. M., Ballalai, J. M., Kuhnert, H., Johnstone, H., et al. (2021). Tropical Atlantic Stratification Response to Late Quaternary Precessional Forcing. Earth Planet. Sci. Lett. 568, 117030. doi:10. 1016/j.epsl.2021.117030

Peterson, L. C., Haug, G. H., Hughen, K. A., and Rohl, U. (2000). Rapid Changes in the Hydrologic Cycle of the Tropical Atlantic during the Last Glacial. Science 290, 1947-1951. doi:10.1126/science.290.5498.1947 
Peterson, R. G., and Stramma, L. (1991). Upper-level Circulation in the South Atlantic Ocean. Prog. Oceanography 26, 1-73. doi:10.1016/0079-6611(91)90006-8

Piacsek, P., Behling, H., Ballalai, J. M., Nogueira, J., Venancio, I. M., and Albuquerque, A. L. S. (2021). Reconstruction of Vegetation and Low Latitude Ocean-Atmosphere Dynamics of the Past 130 Kyr, Based on South American Montane Pollen Types. Glob. Planet. Change 201, 103477. doi:10. 1016/j.gloplacha.2021.103477

Rama-Corredor, O., Martrat, B., Grimalt, J. O., López-Otalvaro, G. E., Flores, J. A., and Sierro, F. (2015). Parallelisms between Sea Surface Temperature Changes in the Western Tropical Atlantic (Guiana Basin) and High Latitude Climate Signals over the Last 140000 Years. Clim. Past 11, 1297-1311. doi:10.5194/ cp-11-1297-2015

Ramos, T. P. A., Ramos, R. T. d. C., and Ramos, S. A. Q. A. (2014). Ichthyofauna of the Parnaíba River Basin, Northeastern Brazil. Biota Neotrop. 14, 1-8. doi:10. 1590/s1676-06020140039

Roberts, W. H. G., and Hopcroft, P. O. (2020). Controls on the Tropical Response to Abrupt Climate Changes. Geophys. Res. Lett. 47, e2020GL087518. doi:10. 1029/2020GL087518

Roberts, W. H. G., Valdes, P. J., and Singarayer, J. S. (2017). Can Energy Fluxes Be Used to Interpret Glacial/interglacial Precipitation Changes in the Tropics. Geophys. Res. Lett. 44, 6373-6382. doi:10.1002/2017GL073103

Rodrigues, R. R., Rothstein, L. M., and Wimbush, M. (2007). Seasonal Variability of the South Equatorial Current Bifurcation in the Atlantic Ocean: A Numerical Study. J. Phys. Oceanogr. 37, 16-30. doi:10.1175/JPO2983.1

Santos, T. P., Ballalai, J. M., Franco, D. R., Oliveira, R. R., Lessa, D. O., Venancio, I. M., et al. (2020). Asymmetric Response of the Subtropical Western South Atlantic Thermocline to the Dansgaard-Oeschger Events of Marine Isotope Stages 5 and 3. Quat. Sci. Rev. 237, 106307. doi:10.1016/j.quascirev.2020.106307

Schneider, T., Bischoff, T., and Haug, G. H. (2014). Migrations and Dynamics of the Intertropical Convergence Zone. Nature 513, 45-53. doi:10.1038/ nature 13636

Schrag, D. P., Adkins, J. F., McIntyre, K., Alexander, J. L., Hodell, D. A., Charles, C. D., et al. (2002). The Oxygen Isotopic Composition of Seawater during the Last Glacial Maximum. Quat. Sci. Rev. 21, 331-342. doi:10.1016/S0277-3791(01) 00110-X

Seo, J., Kang, S. M., and Frierson, D. M. W. (2014). Sensitivity of Intertropical Convergence Zone Movement to the Latitudinal Position of thermal Forcing. J. Clim. 27, 3035-3042. doi:10.1175/JCLI-D-13-00691.1

Stocker, T. F., and Johnsen, S. J. (2003). A Minimum Thermodynamic Model for the Bipolar Seesaw. Paleoceanography 18, a-n. doi:10.1029/2003PA000920

Stramma, L., and England, M. (1999). On the Water Masses and Mean Circulation of the South Atlantic Ocean. J. Geophys. Res. 104, 20863-20883. doi:10.1029/ 1999JC900139

Stramma, L., Fischer, J., and Reppin, J. (1995). The North Brazil Undercurrent. Deep Sea Res. Oceanographic Res. Pap. 42, 773-795. doi:10.1016/0967-0637(95) 00014-W

Tjallingii, R., Claussen, M., Stuut, J.-B. W., Fohlmeister, J., Jahn, A., Bickert, T., et al. (2008). Coherent High- and Low-Latitude Control of the Northwest African Hydrological Balance. Nat. Geosci 1, 670-675. doi:10.1038/ngeo289

Utida, G., Cruz, F. W., Etourneau, J., Bouloubassi, I., Schefuß, E., Vuille, M., et al. (2019). Tropical South Atlantic Influence on Northeastern Brazil Precipitation and ITCZ Displacement during the Past 2300 Years. Sci. Rep. 9, 1698. doi:10. 1038/s41598-018-38003-6

Venancio, I. M., Mulitza, S., Govin, A., Santos, T. P., Lessa, D. O., Albuquerque, A. L. S., et al. (2018). Millennial- to Orbital-Scale Responses of Western Equatorial Atlantic Thermocline Depth to Changes in the Trade Wind System since the Last Interglacial. Paleoceanography and Paleoclimatology 33, 1490-1507. doi:10.1029/2018PA003437
Venancio, I. M., Shimizu, M. H., Santos, T. P., Lessa, D. O., Portilho-Ramos, R. C., Chiessi, C. M., et al. (2020). Changes in Surface Hydrography at the Western Tropical Atlantic during the Younger Dryas. Glob. Planet. Change 184, 103047. doi:10.1016/j.gloplacha.2019.103047

Veres, D., Bazin, L., Landais, A., Toyé Mahamadou Kele, H., Lemieux-Dudon, B., Parrenin, F., et al. (2013). The Antarctic Ice Core Chronology (AICC2012): An Optimized Multi-Parameter and Multi-Site Dating Approach for the last 120 Thousand Years. Clim. Past. 9, 1738-1748. doi:10.5194/cp-9-1733-2013

Wang, X., Auler, A. S., Edwards, R. L., Cheng, H., Cristalli, P. S., Smart, P. L., et al. (2004). Wet Periods in Northeastern Brazil over the Past 210 Kyr Linked to Distant Climate Anomalies. Nature 432, 740-743. doi:10.1038/nature03067

Weldeab, S., Schneider, R. R., and Kölling, M. (2006). Deglacial Sea Surface Temperature and Salinity Increase in the Western Tropical Atlantic in Synchrony with High Latitude Climate Instabilities. Earth Planet. Sci. Lett. 241, 699-706. doi:10.1016/j.epsl.2005.11.012

Weldeab, S., Lea, D. W., Schneider, R. R., and Andersen, N. (2007). 155,000 Years of West African Monsoon and Ocean Thermal Evolution. Science 316, 1303-1307. LP - 1307. doi:10.1126/science.1140461

Wolff, E. W., Chappellaz, J., Blunier, T., Rasmussen, S. O., and Svensson, A. (2010). Millennial-scale Variability during the Last Glacial: The Ice Core Record. Quat. Sci. Rev. 29, 2828-2838. doi:10.1016/j.quascirev.2009.10.013

Xie, S.-P., and Carton, J. A. (2004). "Tropical Atlantic Variability: Patterns, Mechanisms, and Impacts," in Earth's Climate (American Geophysical Union), 121-142. doi:10.1029/147GM07

Yu, S., and Pritchard, M. S. (2019). A strong Role for the AMOC in Partitioning Global Energy Transport and Shifting ITCZ Position in Response to Latitudinally Discrete Solar Forcing in CESM1.2. J. Clim. 32, 2207-2226. doi:10.1175/JCLI-D-18-0360.1

Zhang, Y., Chiessi, C. M., Mulitza, S., Sawakuchi, A. O., Häggi, C., Zabel, M., et al. (2017). Different Precipitation Patterns across Tropical South America during Heinrich and Dansgaard-Oeschger Stadials. Quat. Sci. Rev. 177, 1-9. doi:10. 1016/j.quascirev.2017.10.012

Zhang, Y., Chiessi, C. M., Mulitza, S., Zabel, M., Trindade, R. I. F., Hollanda, M. H. B. M., et al. (2015). Origin of increased terrigenous supply to the NE South American continental margin during Heinrich Stadial 1 and the Younger Dryas. Earth Planet. Sci. Lett. 432, 493-500. doi:10.1016/j.epsl.2015.09.054

Zhuravleva, A., Hüls, M., Tiedemann, R., Bauch, H. A., et al. (2021). A 125-ka Record of Northern South American Precipitation and the Role of High-to-Low Latitude Teleconnections. Quat. Sci. Rev. 270, 107159. doi:10.1016/j.quascirev. 2021.107159

Conflict of Interest: The authors declare that the research was conducted in the absence of any commercial or financial relationships that could be construed as a potential conflict of interest.

Publisher's Note: All claims expressed in this article are solely those of the authors and do not necessarily represent those of their affiliated organizations, or those of the publisher, the editors, and the reviewers. Any product that may be evaluated in this article, or claim that may be made by its manufacturer, is not guaranteed or endorsed by the publisher.

Copyright $\odot 2022$ Venancio, Nascimento, Santos, Belem, Lessa, Tiedemann, Chiessi, Mulitza and Albuquerque. This is an open-access article distributed under the terms of the Creative Commons Attribution License (CC BY). The use, distribution or reproduction in other forums is permitted, provided the original author(s) and the copyright owner(s) are credited and that the original publication in this journal is cited, in accordance with accepted academic practice. No use, distribution or reproduction is permitted which does not comply with these terms. 